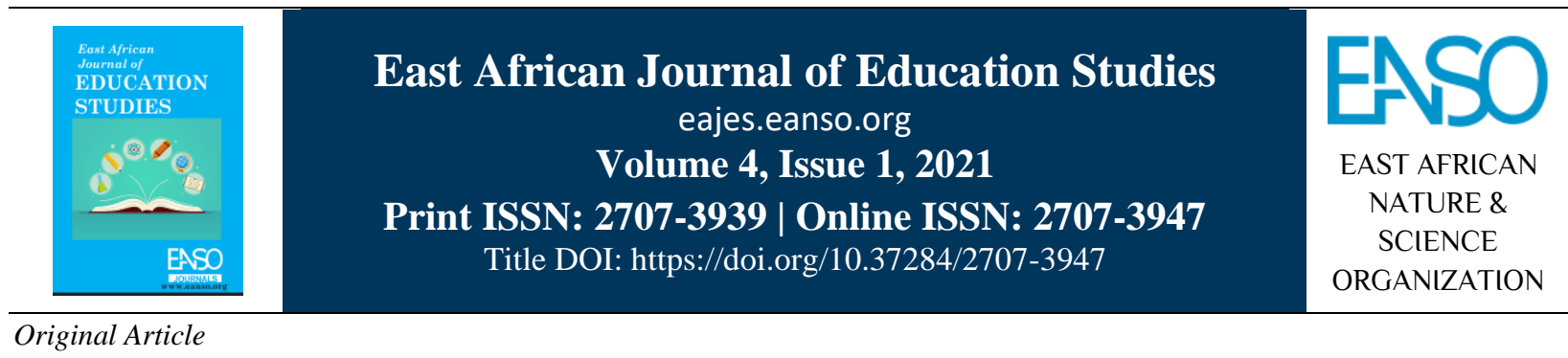

\title{
State-Public University Contractual Relationship Impact on Student's Accessibility Rights: The Agency Theory Perspective.
}

\author{
Dr. Joseph Kimoga, PhD ${ }^{1}$ \\ ${ }^{1}$ Makerere University, P. O. Box 7072, Kampala, Uganda. \\ *Author for Correspondence Email: kimogaj@yahoo.com.
}

Article DOI: https://doi.org/10.37284/eajes.4.1.451

\section{Date Published: ABSTRACT}

30 October 2021 The state-public university contractual relationship constrains public universities to be driven by the state expected level of quality output of
graduates. The relationship reduces institutional substantive and procedural autonomy in specific key areas like student admission. In order to achieve Agency-Theory, good results consonant to the state support, universities are directed to Admission Mechanism,

Procedure, ensure strict scrutiny of those they admit. This locks out many qualifying students from accessing studies at state-funded institutions. This study uses Institutional Autonomy, Access Rights, Higher Education. the perspective of agency theory to assess the impact of state - public university contractual relationship on student's accessibility rights. The interpretive phenomenological analysis enabled to appreciate data collected through self-administered questions given to seven participants in four public and regional universities. The analysis bases on parameters of selection and admission. The study recommends capital grant, national ranking of academic units, and policy imperatives for special interest groups as the means by which sub-Saharan higher education institutions can maximise students' access rights.

\section{APA CITATION}

Kimoga, J. (2021). State-Public University Contractual Relationship Impact on Student's Accessibility Rights: The Agency Theory Perspective. East African Journal of Education Studies, 4(1), 48-60. https://doi.org/10.37284/eajes.4.1.451.

\section{CHICAGO CITATION}

Kimoga, Joseph. 2021. "State-Public University Contractual Relationship Impact on Student's Accessibility Rights: The Agency Theory Perspective”. East African Journal of Education Studies 4 (1), 48-60. https://doi.org/10.37284/eajes.3.1. 451.

Kimoga, J. (2021) "State-Public University Contractual Relationship Impact on Student's Accessibility Rights : The Agency Theory Perspective”, East African Journal of Education Studies, 4(1), pp. 48-60. doi: 10.37284/eajes.4.1. 451. 


\section{IEEE CITATION}

J. Kimoga, "State-Public University Contractual Relationship Impact on Student's Accessibility Rights: The Agency Theory Perspective", EAJES, vol. 4, no. 1, pp. 48-60, Oct. 2021.

\section{MLA CITATION}

Kimoga, Joseph. "State-Public University Contractual Relationship Impact on Student's Accessibility Rights: The Agency Theory Perspective". East African Journal of Education Studies, Vol. 4, no. 1, Oct. 2021, pp. 48-60, doi:10.37284/eajes.4.1. 451.

\section{INTRODUCTION}

Public university budgets in many developing economies are financed by their states. For example, in sub-Saharan countries many universities are state-funded (Oketch, 2016). Therefore, despite their institutional goals of being teaching-intensive, or teaching-research intensive, or researchintensive, many universities strive as well to satisfy the objectives of the financer. Universities are obligated to account for the state input through quality output.

However, the state financial commitments to public universities coupled with inclusive legal directives, instead harden accessibility to public institutions by many qualifying students. For example, in Uganda, to achieve good results consonant to the state support, universities are directed to ensure strict scrutiny of those they admit (Universities and Other Tertiary Institutions Regulations [UOTIR], 2007). The challenge is that this locks out many qualifying students from accessing studies at state-funded institutions and instead opt for resource struggling private institutions that can accommodate them (Matovu, 2018; Mohamedbhai, 2008). This study uses the perspective of agency theory to assess the impact of state - public university contractual relationship on student's accessibility rights. Therefore, the study seeks;

- To assess the nature of the state -public university contractual relationship at admission.

- To examine how the state-public university contractual relationship impacts on students' accessibility rights.

\section{LITERATURE}

Definers of institutional autonomy do not express total institutional freedom from state control. For instance, Salmi (2008, cited in Raza, 2009) defines institutional autonomy as state increasingly exiting from the day-to-day management of the tertiary sector allowing universities to determine their own path. It is "the constantly changing relations between the state and higher education institutions (HEIs) and the degree of control exerted by the state, depending on the national context and circumstances" (Soeparwata, n.d., p. 17). In government-sponsored institutions, the state controls the systems whereas in private sponsored institutions, the state supervises institutions (Raza, 2009). The control in state-sponsored institutions is directed to securing the accountability for the resources injected in them. However, the state supervision of private sponsored institutions is aimed at maintaining the desired standards.

Martin (2013) and Raza (2009) dichotomise institutional autonomy in terms of substantive and procedural. Martin perceives substantive autonomy as giving institutions the freedom to decide in line with their mission and goals and the ability to pursue those decisions. At a reduced level, Raza perceives it in terms of academics and research mainly; curriculum design, research policy, entrance standards, academic staff appointments, awarding degree, etc. Raza's perception which is more of academic than institutional freedom, is covered by Martin's broader view. Nevertheless, for Martin, procedural autonomy relates to administrative freedom devoid of ability to decide on substantive priorities, which Raza calls the nonacademic areas such as budgeting, financing, nonacademic staff appointments, purchasing, and entering into contracts. However, institutions have greater authority to implement them.

Olsen (2009, p. 20) conceptualises a university as "a composite organisation embracing ideas about a community of the learned, an internal democracy, an agency for implementing public policies, and an enterprise in competitive markets". Therefore, as an education institution it has educational vision, mission and values by which it is identified. It is an environment where academics interact in 
knowledge sharing. Specifically, a public institution is that whose statutory existence and operation depends on the public policy laid by the legislative authority of a state and fully or partially managed on the consolidated funds of the state (Guzma'nValenzuela, 2015). Public HEIs exist on statutory basis and operate basing on public policy. In most sub-Saharan contexts, the Ministry in charge of education or any appointed education agency develops most policies that impact on students, staff, faculty and administration. However, for public institutions the national manpower planning agency may determine student enrolment rates, and which programmes to take a given number of students; and the curriculum content is standardised by state decree (Dee, Henkin and Chen, 2000). Although Abrutyn (2009) argues that institutions are the paramount structures facilitating and constraining action, goal setting and decision making, the public institution dependence on state may lessen their procedural autonomy in deciding on substantive issues. Whereas Abrutyn conceptualizes institutional autonomy as the degree of an institution to orient behaviours of various role players towards institutional values, beliefs and norms, the preferred conceptualisation is the power for an institution to govern its own affairs unrestrictedly (Oslen, 2009; Chiang, 2004; Egeberg, 2004). Institutions have a right to function according to their own normative and organisational principles and behaviour logics which may include decisions on budgetary priorities and fundraising initiatives (Oslen, 2009; Ordorika, 2003).

A university formulates institutional policies on student admission and deciding on the nature and number of students to admit and staff to recruit (De Figueiredo-Cowen, 2002). Institutions adapt their internal structures and processes as influenced by nature and number of students admitted, teaching and research, national and social demands and expectations, etc. This necessitates institutional flexibility and responsiveness to these demands without external interference and empowering their units to exercise their autonomy in pursuing to satisfy these demands and expectations (Oslen, 2009; Ordorika, 2003).

Accessing $\mathrm{HE}$ is a global interest. Accessibility generally means being able to reach or obtain a physical or non-physical, spatial or temporal object.
Scholars (Mugisha, 2010; Indabawa, 2006) regard accessibility to $\mathrm{HE}$ as ability of members of various sections of the population to obtain opportunity to enrol in HEIs. Institutions are expected to select and admit students that qualify for the course of study and to take the number that they may manage. Selection is the criteria used to choose the most qualified candidates for entry when the number of applicants is higher than the available places (Harman, 1994). For Harman, procedure is the mode followed in selecting and admitting students to public HE institutions. Admission is the formal acceptance, notification through writing, and enrolling a candidate on a HE studies programme. HEIs have exercised their substantive autonomy using various forms of procedure for selection and admission of students.

Meritocratic procedure bases entirely on individual intelligence and effort (Zimdars, 2007). The academic performance of a candidate determines whether or not they will be admitted and the nature of the course to pursue. Therefore, merit is mainly based on one's individual academic talent and effort rather than ascription traits (Alon and Tienda, 2007).

Affirmative action procedure emphasizes creating equal opportunities for students from disadvantaged background to access HE. Affirmative action extends to gender, disability, and perhaps other factors. It aims at securing opportunities for members of groups of the socially underrepresented (Weisskopf, 2007; Morley and Lugg, 2009). This, however, is positive discrimination. The inner gains of the beneficiary in terms of self-worth and selfesteem may weaken the affirmative action.

Distributive and procedural justice refer to fairness of the distribution of resources and fairness of the procedure for distribution of resources. The assumption is that justice has to be ensured in form of fair representation of all segments of society (Anyan, 2016).

According to Harman (1994), in many situations access to public HEIs is more difficult than to private higher institutions. This is because the state puts control mechanisms and procedures to admit. Selecting and admitting students to HE becomes one of the stages where state-public institution relationship is constrained. 


\section{THEORISATION}

The Agency Theory developed by Jensen and Meckling in 1976, has been used in various situations including organizational behavior (Eisenhardt, 1989). Since education is organizational, the theory applies. According to Eisenhardt, the agency theory can be explained in a process summarized in terms of 'what', 'how', and 'why'. In the context of this study, the principal is the state and the agent is the HEIs.

The 'what' refers to the nature of contractual relationship entered in between the state and HEIs. In most cases, this is an asymmetrical relationship whereby the state assumes a position superior to that of the HEIs. In this sense, the state monitors the behavior of the HEIs with fear that the latter may not effectively and efficiently perform.

The 'how' is the process of regulating the HEIs' behavior. Since HEIs claim more expertise than the state, the state has to depend on the actions of HEIs. However, to maintain position above the expert (HEIs), the state formulates a memorandum of understanding or a contract that binds both.

The 'why' justifies the control actions of the state. Since two parties enter into contract, they have selfinterests which sometimes conflict. It creates problems. In asymmetric information, since the state cannot fully monitor HEIs, the latter uses the opportunity to bend the rules of engagement in order to serve institutional interests (Bendickson, Muldoon, Liguori, \& Davis, 2016). This is why the state regulates the opportunism of the agent (HEIs) by designing a perfect relationship contract in order to control the HEIs' behavior and keep it to the agreed-upon contract. The agency theory explains the nature of state - public university relationship which in exercise affects students' accessibility rights.

Public HEIs in the sub-Saharan region are mandated to decide on student entrance standards in line with their mission and goals. However, since the state is the primary funder of public institutions, the institutional mandate on admission is bordered by the state directions.

\section{UGANDAN CASE: STATE-PUBLIC UNIVERSITY CONTRACTUAL RELATIONSHIP}

\section{What: Nature of Relationship}

In Uganda, there are currently nine public universities and forty-six private universities (NCHE, 2020). Public universities are majorly funded by the state using national consolidated funds, a privilege that private institutions do not have (BMAU, 2018). The state funding includes salaries, infrastructure, research projects, etc. This support is intended to enable public institutions possess good facilities, provide good teachinglearning environment, and provide quality services to students. The state financial commitment to public institutions is prompted by the promulgation of The Constitution of Uganda (1995) national educational objective 18 (b) that, "The State shall take appropriate measures to afford every citizen equal opportunity to attain the highest educational standard possible." And a later reiteration in article 30 that, "All persons have a right to education." Committing to ensure a better facilitated HE is a state response to the constitutional promulgation. Therefore, the facilitated HEIs are duty-bound to make deliverables in response to the constitutional promulgations.

\section{How: ensuring the contractual relationship}

For the state to monitor HEIs' adherence to constitutional objective, a HE law named as 'Universities and Other Tertiary Institutions Act (UOTIA), 2001', as amended in 2006, was legislated. Within this law, an organ known as National Council for Higher Education (NCHE) was created. Its main role is to regulate HEIs in Uganda by implementing the UOTIA, 2001.

\section{Why: regulating admission parameters}

It states in article 28(1) that, "admission to a Public University shall be open to all qualified citizens of (country) and without discrimination." The 'all qualified citizens' in (country) includes every Advanced Certificate holder that has a minimum score of two principle passes. The lowest principle pass is ' $E$ ' weighing ' 2 ' points while the highest is ' $A$ ' weighing ' 6 ' points. Therefore, a minimum score of 2 'Es' is equal to '4' points. 
Basing on the meritocratic admission standard, article 28(3), states that admission "shall take into consideration affirmative action in favour of marginalized groups based on gender, disability, and disadvantaged schools." The state affirmative action attracted a system of granting 1.5 extra points to every female entrant, and every entrant with a disability. Public institutions have defined the nature of disability they consider for affirmative action. The score at the Advanced level added to the extra points should raise a total that meets the cutoff points for one to join a public institution. The affirmative, however, does not attract financial support to prospective applicants.

Article 28 (4) states that admission shall consider "persons with special talents in sports, music and other social activities for their enhancement." This task HEIs to admit highly talented students in the mentioned areas. Despite specifying the nature of talents supported, the law does not articulate the degree of talent if at all measurable, and the criteria to use when determining the talent. Unlike affirmative action where bonus points are stipulated, the special talent beneficially must obtain the cut-off points to access state financial support.

Since remotely located schools are disadvantaged by factors like poor roads and infrastructure, the state adopted the distributive justice procedure and introduced the district-quota system which allows an equal number of students who have obtained Advanced level certificates from every district to join HEIs. This form attracts financial support to selected entrants that obtain the cut-off points. Therefore, these state interventions are asymmetrical in as far as HEIs have to consider them at admission.

\section{METHOD}

I used the Interpretative Phenomenological Analysis (IPA) (Brocki \& Wearden, 2006). This is an inductive approach to research that establishes understanding after engaging with a phenomenon. Using the agency theory to assess the state-public institution contractual relationship, enabled me to examine its impact on student's accessibility rights.
A pack of self-administered questions below was posted to every academic registrar in each of the four universities.

- What roles are played by the state and university in the procedures of the selection and admission of students in universities?

How does the state-public university contractual relationship in the selection and admission procedures impact on students' accessibility rights?

- What roles are played by the state and university in the mechanism of the selection and

admission of students in universities?

- How does the state-public university contractual relationship in the selection and

admission mechanism impact on students' accessibility rights?

I requested them to fill out a copy and to give out other copies to Unit registrars and their assistants. The filled copies were to be sent back as a single pack in a pre-paid envelope after a period of one month.

The methods of self-administered questions and the document study of the Constitution of Uganda and the HE law (UOTIA, 2001) strengthened the trustworthiness of this study because the analysis of the participants' responses is linked to the national documents explained. The description of the study processes sets the basis for any intention for confirmation and transferability of findings to other similar contexts.

\section{Sample}

Four public universities (Makerere, Kyambogo, Mbarara, and Gulu) in Uganda were preferred being some of the main public universities that should be accessible to all qualifying citizens. They are directly affected by the state decisions, policies, and laws and are financially supported by them.

Since data were collected during the COVID-19 lockdown, I preferred to use open and closed-ended self-administered questions to ascertain the nature 
East African Journal of Education Studies, Volume 4, Issue 1, 2021

Article DOI: https://doi.org/10.37284/eajes.4.1.451

of selection and admission mechanism and procedure.

University Registrar and College/Unit Registrars and their assistants were the most preferred participants in this study because they are directly

concerned with student selection and admission. Registrars and their assistants are few in the selected institutions, the reason for selecting only seven participants from each university. Their voices were analysed following the categories of mechanism and procedure.

Table 1: Study participants code-named

\begin{tabular}{llll}
\hline Makerere & Kyambogo & Mbarara & Gulu \\
\hline Mk1 & Ky1 & Mb1 & Gu1 \\
Mk2 & Ky2 & Mb2 & Gu2 \\
Mk3 & Ky3 & Mb3 & Gu3 \\
Mk4 & Ky4 & Mb4 & Gu4 \\
Mk5 & Ky5 & Mb5 & Gu5 \\
Mk6 & Ky6 & Mb6 & Gu6 \\
Mk7 & Ky7 & Mb7 & Gu7 \\
\hline
\end{tabular}

\section{Limitations}

Because of the type of cluster selected for data collection, this study did not consider selection by gender, age, origin, education, etc. Moreover, the

study did not cover all public universities but simply the regional ones. In addition, it left out private universities. Even the regional universities were not taken as representative but simply multiple cases each of which provides a unique perspective.

\section{FINDINGS}

\section{Selection and admission procedure}

Table 2: The university and state roles in the selection and admission procedures

\begin{tabular}{llll}
\hline Item & University & Ministry & $\begin{array}{l}\text { I don't } \\
\text { know }\end{array}$ \\
\hline $\begin{array}{l}\text { Who determines which university programme an applicant should } \\
\text { pursue? }\end{array}$ & 24 & 04 \\
$\begin{array}{l}\text { Who determines which academically excellent student at UACE } \\
\text { qualifies for State sponsorship? }\end{array}$ & 00 & 00 \\
$\begin{array}{l}\text { Who determines which academic programme to include on the list of } \\
\text { those where State sponsors students? }\end{array}$ & 04 & 24 & 00 \\
$\begin{array}{l}\text { Who determines which student qualifies for the district quota? } \\
\text { Who determines which talented student qualifies for State sponsorship? }\end{array}$ & 06 & 26 & 00 \\
Who determines which disabled students qualify for State sponsorship? & 26 & 02 & 00 \\
\hline
\end{tabular}

Source: Findings on the university and state roles in the selection and admission procedures in public universities

Universities offer different disciplines in sciences and humanities fields which are revised in a period determined by the NCHE. The disciplines fit in and respond to national needs and objectives (UOTIA, 2001). Students freely apply for any program that suits their interests and merit. Mb4, Mb7, Gu1, Gu2, Mk4 shared that the filled application forms are sent to respective departments for boards to decide which qualifying applicants to shortlist. The list is sent back to the registrar who issues admission letters to the selected students. This was affirmed by a total of 24 out of 28 in Item 1, Table 2 that the university takes the final prerogative on which programme an applicant should pursue. 
All the 28 study participants in Item 2 of Table 2 indicated that public universities exercise the substantive mandate to decide on who to qualify for state sponsorship. However, the state sponsorship is limited to specific programmes which are deemed to be of special relevance to the nation. In Item 3 of Table 2, a total of 24 participants indicated that the Ministry is in charge of determining which academic programmes to include on the list of those where the state sponsors students. Mk6, Ky4, Ky6, Gu6, and in particular Mb7 shared that, "the university can only propose programmes to state but does not have the freedom to select the programmes that fit state sponsorship". Therefore, the Ministry stipulates "day programmes which have places under state sponsorship through national merit ..." Programmes not included on the list, provided they are accredited by the NCHE, can be pursued on a private basis.

Gu6, Mk3, Mk1, Ky5, and particularly Mb4 stated that;

there are many places that lack electricity which could be used for lighting and powering computer sets. Students in schools located in such areas are limited in the time they spend on reading. They cannot read in the night. They have no means of using computers.

As a matter of fact, their performance may not be as good as that of students who went to betterfacilitated schools. In a bid to ensure distributive justice, the state established admitting students from districts through a quota system. This practice offers a maximum of four slots to students from every district to access free HE. The selection considers the candidate's performance. Therefore, a district that may lack candidates who qualify for the national set academic standards loses out. Item 4 of Table 2 indicates that 22 participants confirmed that students who qualify for district quota state funding are selected at the district office in charge of education. The names of the selectees are forwarded to the Ministry which further distributes them to various public institutions.

As stated in the HE laws article 28(4), admission shall consider "persons with special talents in sports, music and other social activities for their enhancement", public universities moved to implement it (UOTIA, 2001). 26 participants in
Item 5 of Table 2 confirmed that the university has the mandate to select which talented students are suitable for state sponsorship. Like other HEIs, public universities get involved in inter-institutional sports nationwide. As revealed by Mk3,

... the University makes plan to meet the need for students talented in the co-curricular activities. Therefore, the concerned department participates in carefully selecting the qualifying students.

This suggests that public institutions have the mandate to decide on the nature of talent required to boost their sports activities. They as well participate in choosing who to admit to that effect.

The affirmative action in article (3) offered to students with disabilities tasks public institutions to admit students of various impairments even if facilities may not be available (UOTIA, 2001). A university has the duty to identify which students with disabilities to admit. This was confirmed by 26 participants in Item 6 of Table 2. Mb5, Mb7, Gu1, $\mathrm{Ky} 1, \mathrm{Ky} 5$, and Mk2 further confirmed that, on the application form, one with a disability has to indicate its nature. If the disability falls within the category considered for affirmative action, the university further takes the step to verify the applicant's disability. However, as revealed by Ky6, "a university cannot reject the wish of a student with a disability who prefers to be educated at that particular public university". Therefore, lack of facilities may not constitute a reason for rejecting the student's wish. Since public universities are majorly funded by the state, budgetary allocations are expected to include facilitating those with disabilities. 
East African Journal of Education Studies, Volume 4, Issue 1, 2021

Article DOI: https://doi.org/10.37284/eajes.4.1.451

Selection and Admission Mechanism

Table 3: The university and state roles in the selection and admission mechanism

\begin{tabular}{llll}
\hline Item & University & Ministry & $\begin{array}{l}\text { I don't } \\
\text { know }\end{array}$ \\
\hline Who controls the PUJAB form? & 00 & 28 & 00 \\
\hline Who determines the weighing of A-Level subjects? & 02 & 26 & 00 \\
\hline $\begin{array}{l}\text { Who determines the cut-off points for a particular academic } \\
\text { programme? }\end{array}$ & 28 & 00 & 00 \\
\hline $\begin{array}{l}\text { Who determines the non-refundable application fee for study at } \\
\text { the university? }\end{array}$ & 28 & 00 \\
\hline $\begin{array}{l}\text { Who determines which university academic units to give pre- } \\
\text { entry exams? }\end{array}$ & 00 & 00 \\
\hline
\end{tabular}

Source: Findings on the university and state roles in the selection and admission mechanism in public universities

The Ministry of Education and Sports (MoE\&S) designed that every candidate for HE has to fill a Public Universities Joint Admissions Board (PUJAB) application. This is done before or immediately after sitting the (country) Advanced Certificate of Education (UACE) examination. It enlists a candidate for consideration in accessing state sponsorship in a public university in case they satisfy the requirements of; at least five passes in (country) Certificate of Education (UCE), and at least two Advanced Level passes at the same sitting of the UACE examination (MoE\&S, 2013). Gu5, $\mathrm{Gu} 2$, and particularly Ky1 clarified that "although all candidates are expected to fill the PUJAB form, it mainly benefits those who perform excellently to merit the state sponsorship. Some candidates fail to fill it for some reasons, for example, lack of application fees". Therefore, a candidate who does not meet the standards for state sponsorship, whether filled the PUJAB form or not, but meets the minimum standards (UOTIA, 2001) has to apply to a public university for consideration as a private student (Makerere University, 2015). In Item 1 of Table 3, all participants acknowledged that the PUJAB mechanism is entirely controlled by the Ministry.

Item 2 of Table 3 confirms with a figure of 26 out of 28 that the weighing system which applies to all public institutions is determined by the Ministry of Education and Sports (MoE \& S) (2013). The Ministry states that 'all subjects at the Advanced level of education are grouped in four categories; namely, essential, relevant, desirable and others and weighed as 3, 2, 1, and 0.5 respectively'. This weighing system is paramount in all universities and cannot be replaced by any institutionally designed system. It is a general norm that has to be upheld by every university and ensured by the NCHE (UOTIA, 2001). It is one of the levels where universities do not decide on weighing subjects. Indeed, Gu1, Gu7, Mk2, Mk5, Ky2, Ky3, Ky4, and in particular Mb5 confirmed that,

Deciding on the weight of subjects is the role of the ministry department in charge of HE. Their decision depends on the government's intentions and objectives for the nation. If for example, they realize that sciences are more desirable, then they are weighed highly.

However, Mk2, Mk5, Ky4, Mb5, Mb6, and Gu6 shared that despite all that, the cut-off points as a basis for determining those who qualify for a particular programme and state sponsorship are determined by a particular university. This was also evidenced by a unanimous response of 28 participants as indicated in Item 3 of Table 3. Nevertheless, on the application form, applicants are expected to indicate four study programmes in order of preference. Therefore, neither student nor Ministry may force a university to allow a candidate on a programme basing on A-level subject weighing. The institutional autonomy exercised in putting a mechanism of cut-off points is appropriate to control the quality of the input.

Item 3 of Table 3 indicates all 28 participants confirming that an institution exercises the freedom 
of determining a non-refundable fee for the application. Mk2, Mk7, Ky4, Mb6, Gu2, Gu3, and Gu7 explained that this fee is paid in the bank using university paying-in-slip, after which an application form and other relevant information are obtainable from the admissions office. Relevant academic slips of UCE and UACE and paying-in-slip are attached and submitted to the admissions office. However, since it is a public institution, the funds collected from this application mechanism are remitted to the national treasury like any other collection from privately sponsored students.

Nevertheless, as a mechanism, in public universities, all applicants for Bachelor of Laws must have sat and passed the pre-entry examination set by the admitting university. In Item 5 of Table 3, participants unanimously confirmed that the mechanism of deciding which academic unit to provide a pre-entry exam is reserved for the university. Participant Ky4 stated that "the pre-entry examination is one of those indicators of institutional freedom where a university decides to re-examine candidates to the School of Laws". Other participants (Mk5, Ky6, Gu4, and Gu1) further explained that the entry exam helps to reduce the number of applicants. Some programmes attract massive qualifying applicants which number may not be managed by the faculty. Reducing them through this means is a very sensible way. Furthermore, Mk5 added that "a similar practice should be extended to other colleges because there is declining trust in the genuineness of students' performance at UACE".

\section{STATE-UNIVERSITY CONTRACTUAL RELATIONSHIP IMPACT ON STUDENTS' ACCESSIBILITY RIGHTS}

\section{Selection and Admission Procedures}

The selection process reflects loopholes. Institutions establish controls to limit the number of applicants. Public HEIs set 'cut-off points' for every academic programme which are far higher than the total ' 4 ' points in case one obtains two 'Es'. The intention is to admit a level of quality that will enable institutions to deliver on the state's expectations. This, however, denies many qualifying candidates with two 'Es' but below the 'cut-off points' chance to access a public institution. The constitutional right stated in the commitment of affording "every citizen equal opportunity" (Objective 18(1)) to education is violated. In other instances, students are admitted to programs, not of their choice. $\mathrm{Mk} 3$ and $\mathrm{Ky} 2$ intimated that, if one fails to raise the specified mark, one is admitted to a programme whose cut-off mark is lower. By so doing, public universities encroach on the rights of applicants who are admitted to programmes different from their preferred ones.

The decision by universities on who to benefit from state sponsorship creates unfairness in the process. Dedicating tax payer's money to fully sponsor the best-performing denies the less performing right to enjoy the same benefits. The equality claimed in objective 18(1) is lost in the meritorious practice. In addition, since sponsorship is strictly tied to specific programmes, there is a possibility of admitting some best-performing students to programmes that are not their best. Their right to choose is limited and sometimes denied to benefit from financial support. The challenge remains for the candidate to accept any programme that the university may choose for them.

The public university move to consider 'persons with special talents in sports, music and other social activities for their enhancement' is commendable. However, judging the expertise of the talented is contestable. The documents data indicate no clear standards to determine talent. The practice is prone to corruption and nepotism, which blurs the rights of the genuinely talented to access HE. Those who are genuinely talented may not benefit from the scheme.

The state affirmative action that caters to the disabled is a positive consideration to them. However, in situations where public institutions are constrained by the shortage of funds to ensure a proper infrastructure for people living with disabilities, applicants with disabilities are affected. When they learn that there are no facilities to support their form of disability, most get frustrated and decline the admission offer. This hampers their right to access education which is enshrined in the Constitution of Uganda. 


\section{Selection and Admission Mechanism}

The state put in place the PUJAB as a mechanism for accessing government financial support for qualifying candidates for HE. This would increase state commitment to widening equal access to HE. Unfortunately, participants indicated that not all candidates can fill the form because of high application fees. Therefore, the PUJAB reduces candidates' chances to benefit from state funding. As a mechanism used to enable those to access state sponsorship, it is unfair in as far as those who do not fill it due to any reason are automatically eliminated.

The study found that the cut-off points set by institutions are a strong gatekeeper for sieving out those who qualify. Despite one's preference for a programme, they may be redirected to a less preferred option. However, this in a way limits students' right to access a program they prefer to undertake.

The institutional-based system of entry exams also helps to sieve out the most appropriate students for the program. It reduces the number of applicants. However, the rights of those genuinely interested in the program are violated if they are eliminated by failure to perform in the entrance exam. Therefore, whereas universities succeed in controlling the number of applicants to some programmes, there is limited right to access a programme where they qualify and prefer as per normal standards.

\section{DISCUSSION}

Although there are other options provided for in the UOTIA, 2001 namely; affirmative action and distributive, the main admission option is by academic merit (Zimdars, 2007). In the light of deciding on who to admit and on which programme, the findings align with scholars that universities reserve their substantive right (Oslen, 2009; Chiang, 2004; Egeberg, 2004) which, however, is exercised within the state limits.

Nevertheless, one of the diversifications brought by the massification of HE was the funding sources (Martin, 2013). In (country), the state moved away from funding studies for all students to support the best few. Students who do not merit state funding turned to private sponsorship (Mugizi, 2018; Amina and Turyahebwa, 2015; Mugabi, 2009). Therefore, in public institutions even with cut-off points determined, there are exceptional super performing cases that merit full sponsorship by the state. In (country) the state offers to fully sponsor at least 4000 every year. As Alon and Tienda (2007) argue, meriting state sponsorship is mainly based on one's individual academic talent and effort rather than ascription traits. However, since the state makes the manpower planning (Dee, Henkin \& Chen, 2000), she supports the best performing in programmes that feed sectors that are key to the national growth. Martin (2013) and Owusu-Ansah (2015) highlight that, although institutions may have the substantive autonomy to decide on their mission and goals, their freedom is limited when it comes to deciding which programmes are suitable for enrolling students on state sponsorship.

The distributive justice is reflected in the district quota system. According to Anyan (2016), distributive justice is a means of allocating resources in equal terms to benefit all. (country) being a developing nation, has places that are too remote to receive the basic educational and infrastructural resources. The option of distributive justice has enabled many in remote areas to access $\mathrm{HE}$ at public institutions. University departments can simply retain their substantive right to accept selectees who meet the per programme cut-off points (Oslen, 2009; Ordorika, 2003), but do not have any control over the selection process of candidates for district quota.

Although an option for considering highly talented students is upheld in public institutions, the findings indicate that one with poor grades may not be admitted. The selection is in this case according to merit (Alon and Tienda, 2007). This suggests that public institutions, exercising their substantive and procedural autonomy (Martin, 2013; Raza, 2009), not only decide on the nature of talent required to boost their sports activities but also on who to admit in the same docket. Universities as well decide on the nature of the disability and who to admit. Following established guidelines, universities are able to ascertain who to benefit from affirmative action (Weisskopf, 2007; Morley and Lugg, 2009). Since public universities are majorly funded by the state, budgetary allocations are expected to include facilitating those with disabilities. However, 
findings concur with Raza (2009) that although institutions decide on what to spend on, they are restrained by the state to decide on substantive priorities such as financing some budgetary items (Martin, 2013).

Money drawn from national coffers where all citizens contribute as taxpayers (BMAU, 2018; Guzma'n-Valenzuela, 2015) should be accessible to all qualifying citizens without special application. Some participants intimated that the PUJAB despite being a mechanism used to access state sponsorship, it discriminates against those who do not fill it.

As Soeparwata (n. d.) avers, institutional autonomy is a degree of state control depending on national interests and circumstances. This reflects that ideal institutional autonomy from the state is not possible (Lamb, 2000). Institutional weighing of subjects is based on its relevance to national objectives. The study indicated that the $\operatorname{MoE} \& S$, as the main state overseer of education, and through the NCHE charged with regulating HE in the country, oversee the weighing of HE subjects.

Moreover, the findings affirm that institutional autonomy exercised in putting a mechanism of cutoff points is appropriate to control the quality of the input. This resonates with De Figueiredo-Cowen (2002) that a university sets perimeters for determining the quality and quantity of student intake. It depends on a level of institutional autonomy from the state for their departments to determine who to admit (Oslen, 2009; Chiang, 2004; Egeberg, 2004; Ordorika, 2003).

\section{CONCLUSION AND RECOMMENDATION: PROPOSING AN INSTITUTIONAL PROCEDURAL SYSTEM}

Capital grant: The findings explored financial issue as central in HE. There is apparent unfairness in allocating tax-payer's money to the best performing students. Other students are denied right to access a programme of their choice and settle for the less preferred in order to access the state funding. Many students talented in sports miss out on financial support. And charging application fees hinders some very poor from accessing HE. Therefore, the glaring gaps in equitable access to national funds, require government to cease paying for selected students. A per head system of full or half support to all students in HE, whether in public or private institutions, should be adopted. Institutions should instead provide bursaries and grants that may be applied for by those on merit, or competed for.

National ranking of academic units: Programme preference also prominently stood out. Students on state support expressed displeasure over being admitted to a programme in an institution other than their choice due to failure to raise the cut off points of a preferred institution. Others noted that they access a programme in a less performing department simply because it is where government financial support is committed. The ranking of many sub-Saharan HE institutions is based on the performance of the whole institution, disregarding weak and strong departments therein. Adopting a system whereby individual academic units in all universities are nationally ranked can assist prospective applicants to make a more informed choice of which academic unit to apply to regardless of the university.

Policy imperative: Poor infrastructure violates the rights of many students. Many institutions lack proper facilities for people with disability. Therefore, many prospective students with disabilities decline the offer for programmes of their choice and in their preferred institutions if they lack proper facilities. In many sub-Saharan HEIs, policies on the well-being of special interest groups are not realised. Agencies in charge on monitoring standards in HEIs should ensure that it is a penalty attractive imperative for failure to implement the policies affecting special interest groups.

\section{REFERENCES}

Abrutyn, S. (2009). Toward a general theory of institutional autonomy. Sociological Theory, 27(4), 449-465.

Anyan, J. (2016). Persistent elitism in access to higher education in Ghana.

Bendickson, J., Muldoon, J., Liguori, E. W., \& Davis, P. E. (2016). Agency theory: background and epistemology. Journal of Management History. 
BMAU (2018). Funding of Public Universities in (country): what are the issues? BRIEFING PAPER (24/18) Ministry of Finance, Planning and Economic Development. Retrieved on www.finance.go.ug

Brocki, J. M., \& Wearden, A. J. (2006). A critical evaluation of the use of interpretative phenomenological analysis (IPA) in health psychology. Psychology and health, 21(1), 87108.

Chiang, L. C. (2004). The relationship between university autonomy and funding in England and Taiwan. Higher Education, 48(2), 189-212.

de Figueired-Cowen, M. (2002). Latin American universities, academic freedom and autonomy: a long-term myth? Comparative Education, 38(4), 471-484.

Dee, J. R., Henkin, A. B., \& Chen, J. H. H. (2000). Faculty autonomy: perspectives from Taiwan. Higher Education, 40(2), 203-216.

Egeberg, M. (2004). Organising Institutional Autonomy in a Political Context: Vbenduring Tensions in the European Commission's Development (No. 2). ARENA.

Eisenhardt, K. M. (1989). Agency theory: An assessment and review. Academy of management review, 14(1), 57-74.

Mohamedbhai, G. (2008). The effects of massification on higher education in Africa (pp. 20-24). Association of African University Press.

Guzmán-Valenzuela, C. (2016). Unfolding the meaning of public (s) in universities: toward the transformative university. Higher Education, 71(5), 667-679.

Harman, G. (1994). Student selection and admission to higher education: Policies and practices in the Asian region. Higher Education, 27(3), 313339.

Indabawa, S. A. (2006). Educational access for girls: The case of Kano State of Nigeria. In Widening access to education as social justice (pp. 380-393). Springer, Dordrecht. (university1 name withheld) University (2015). Undergraduate private admissions. Retrieved from http://application.mak.ac.(country)/eisweb/

Martin, M. (2013). Increased autonomy for universities in Asia: How to make it work? International Institute for Educational Planning (IIEP) Policy Brief on Higher Education $\mathrm{N}^{\circ} 4$. Retrieved on http//www.iiep.unesco.org

Matovu, M. (2018). Massification or Quality of Graduates?

Morley, L., \& Lugg, R. (2009). Mapping meritocracy: Intersecting gender, poverty and higher educational opportunity structures. Higher Education Policy, 22(1), 3760.

Mugabi, H. (2009). Private universities in Uganda: Growth and role (s) in the provision of higher education. In Fourth Regional Conference on Higher Education Research for Sustainable Development in Africa, Kampala, Uganda.

Mugisha Baine, E. M. (2010). Privatisation of higher education in Uganda and the global gender justice ideal: uneasy bed fellows? Educational Review, 62(3), 315-328.

Ministry of Education \& Sports (2013). Information on public universities joint admissions 2013/2014 academic year. (country): (city name withheld).

Mugizi, W. (2018). The role of higher education in achieving Uganda vision 2040. Elixir Int. J, 115, 49831-49837.

Amina, N., \& Turyahebwa, A. (2015). Institutional Efficiency in Selected Universities in Uganda. Journal of Education and Practice, 6(10), 90-96.

Oketch, M. (2016). Financing higher education in (continental regional name withheld): some reflections and implications for sustainable development. Higher Education volume 72, pages525-539 
Olsen, J. P. (2009). Democratic government, institutional autonomy and the dynamics of change. West European Politics, 32(3), 439-465.

Ordorika, I. (2003). The limits of university autonomy: Power and politics at the Universidad Nacional Autónoma de México.Higher Education, 46(3), 361-388.

Owusu-Ansah, C. (2015). Academic Freedom: Its Relevance and Challenges for Public Universities in Ghana Today. Journal of Education and Practice, 6(5), 173-179.

Raza, R. (2009). Examining autonomy and accountability in public and private tertiary institutions. Human Development Network: World Bank.

Alon, S., \& Tienda, M. (2007). Diversity, opportunity, and the shifting meritocracy in higher education. American Sociological Review, 72(4), 487-511.

Lamb, T. (2000). Learner autonomy, teacher autonomy: Future directions. B. Sinclair, \& I. McGrath (Eds.). Harlow: Longman.
Soeparwata, A. I. (2016). Institutional Autonomy of Universities in Theory and Practice: A qualitative Research on decentralized Financial and Human Resource Competences (Bachelor's thesis, University of Twente).

The Constitution of the Republic of Uganda (1995). Ministry of Justice and Constitutional Affairs: (city name withheld).

Universities and other Tertiary Institutions Regulations (2007). Minimum Entry Requirements for Admission to Universities or Other Tertiary Institutions. Statutory Instruments Supplement to The (country) Gazette No. 72, Volume C by Order of the Government.

Weisskopf, T. E. (2007). Affirmative action in higher education. Seminar, 569, January: 1-7.

Zimdars, A. (2007). Challenges to meritocracy? A study of the social mechanisms in student selection and attainment at the University of Oxford. 